\title{
ESPACIALIDAD INTERIOR DE LAS RIMAS BECQUERIANAS
}

\section{Introducción}

Vigencia de Bécquer. Hace ya varios años escribl un minucioso análisis cstilístico de las Rimas. En él estudié el tejido poético de los versos becquerianos, la f́ntima relación entre fondo y forma y di prucbas cjemplares de por qué el poeta sevillano encabeza la poesía coutcuporánca española, al tener plena conciencia de la profunda relación que existe en todo poema entre forma y contenido, según los evidencia la rima V. "Bécquer ha resistido, resiste y resistirá la erosión de los años: una hábil técnica fundamenta y enmarca la colierencia de sus visiones, de su mundo interior; da cuerpo y solidez a lo etéreo y vagoroso; fija el sentimiento y establece la relación inteligible que une a todos estos clementos entre sí. La sencillez becqueriana y la belleza de las Rimas no emanan de una ingenuidad lírica ni de una inconsciente espontaneidad, sino de una inteligente complejidad, de un intenso y activo pensamiento, de una conciencia vigilante. El valor de la poesía becqueriana reside no sólo en "el dolorido sentir", sino en un profundo sentido de la responsabilidad artístican. 1

Cuando yo escribía estas líneas pensaba en la vigencia de Bécquer deutro de la poesía española anterior a la guerra civil: pensaba en Juan Ramón Jiménez, en Antonio Machado, en los poetas de la generación del 27. Pero ahora, en el centenario de su muerte, me pregunto: ¿qué ofrece Bécquer a los poetas españoles de hoy, a los que han sufrido la experiencia de la guerra, de la posguerra o del destierro? ¿Cuál es su vigencia, más allá -o más acá- de la forma conscientemente artística?

1 Conctin Zardoya, Poesía española contemporánea. Esludios temalicos y estillsticos, Madrid, Guadarrama, 196r, p. 89. 
Releo las Rimas, a un nivel existencial y desde nuestro tiempo, y me parecen actualísimas: en ellas advierto la angustia temporal, una constante preocupación por el ser y la muerte, por el saber y no saber, un anhelo de verdad que - frustrado, casi siempre - tiene que refugiarse en el sueño. Las Rimas son actuales porque, en ellas, el hombre es un ansia perpetua, un anlelo de kalgo mejor» (XV). Bécquer se preocupaba por el destino del hombre y el destino del poeta: de ahí su vigencia para nosotros. Identificaba la vida con el sufrimiento: como muchos de nosotros, en esta hora del mundo. La insensibilidad, para él, era no-vida, inuerte o pre-muerte. Para muchos de nosotros, hoy, son muertosvivos los que desprecian o no se apiadan del negro, del niño de Biafra o del Vietnam, de los hambrientos, de los encarcelados, de los enfermos, etcétera. Este dolor - tiempo vivido- hace envejecer prematuramente $y$, en esta dolorosa maduración, el tiempo vital es rapidísimo (XLIII). $Y$ hasta el espacio se hace tiempo en algunas rimas: el ser, en ellas, se está siempre haciendo y deshaciendo. Lo verdadero, lo que dura, para Bécquer, está más allá del espacio y el tiempo. El vivir y el ser devienen sombras porque el presente es, al instante, pasado. Las estructuras y objetos temporales son abundantisimos en las Rimas. Bécquer es especialmente sensible a todo lo que transita, pasa y desaparece. De alí que sus poemas no presenten nunca formas cerradas ni conclusas: el último verso de cada rima se sobrepasa a sí mismo, vibra y resuena hasta extinguirse en el alma del lector. Esta fuerza propagadora y comunicativa de las Rimas es otra de sus vigencias. Bécquer estaba siempre inseguro y, por tanto, abierto siempre a las llamadas de lo sobrerreal. El anor le revelaba, por otra parte - como a muchos de nosotros-, algunos misterios ontológicos y metafísicos. Sólo el amor unifica los tiempos vitales, unifica la otredad de los seres. Pero el amor también es ticmpo: hace envejecer (XLIII). El desamor es tienpo imposible, angustia existencial. El amor traicionado es una pre-muerte; el amante, un "mucrto en pie» (XIVI). Hay en las Rimas, además, un sentido sacrificial del amor (LI): Bécquer regalaría todo el tiempo (vital) sólo por conocer la realidad interior y exterior del amor. Este anhelo de penetrar el más allá psíquico, o lo que no podemos ver por las máscaras de la apariencia, es un ansia muy contemporánea. Bécquer intenta penetrar el espacio y su más allá, buscando lo verdadero. ¿Alcanza un trasmundo?, ¿un trascielo?, ¿la nada?, ¿lo intemporal?, ¿el trastiempo? Impreciso es todo: el hombre no sabe nada, a pesar de que sabe muchas cosas. Bécquer también quiere llegar al trasfondo del corazón humano: cncuentra la nada psíquica (XIVII). Siente o presiente la náusea sartreana. En la rima XII vemos dos maneras del ser frente a frente: el 
choque del ser temporal con el ser esencial, de la existencia con la esencia. Bécquer, a veces, encuentra en lo que es un trasunto de otra realidad. Hay que subir a la luz. X esta superación de lo corpóreo algunos de nosotros la entendemos muy bien. Todo es posible para el poeta, parecen decirnos las Rimas: hasta el milagro de volar y ascender desde el dolor de la vida humana, trascendiéndola. Su insatisfacción ante lo real cs hermana de nuestra insatisfacción ante muchas realidades de nuestra época. Finalmente, nos emociona la empalia universal que trasciende de muchos poemas becquerianos.

I,as Rimas - por su dimensión interior, humana, ontológica y trascendente- son actuales y lo serán siempre. Bécquer es un poeta eternamente vigente: no habitará el olvido que él alguna vez deseaba.

Iin el centenario de su muerte nos proponemos estudiar a fondo lo que nos parece la triple dimensión matriz de las Rimas: el Ser, el Tiempo y el Lispacio. Al analizar la relación coherente que existe entre ellos, llegaremos a establecer, una vez más, la coherencia temática de la poesía becqueriana. Y se nos revelará claramente el omniverso de Bécquer en esas tres dimensiones fundamentales, con sus acontecimientos y sus cambios, coordinados y coherentes.

Hoy nos proponemos examinar aquil la 'espacialidad' interior de las Rimas. 'Lo de fuera' carecería de significado si no apareciera en el poema inserto ell un adentro o en referencia a él. El intimismo de la poesía becqueriana es tan intenso que 'los espacios interiores' lo fundamentan. La presencia de los elementos cósmicos renueva, sí, el ser y los espacios fntimos del poeta, pero éstos son previos a aquéllos originariamente, pues están ligados a la existencia misma del hombre creador, al temple de su alma. En constante proceso de sístole y diástole, se influyen mutuamente en el trance creador de la subjetividad. El espacio interior se inserta en el de fuera al convertirlo en arte y en poesía. En el cosmos y cn los objetos que pueblan su mundo sondea el poeta la profundidad de su propia naturaleza, pero que le es previa ab origine. El cosmos le sirve de espejo o de catalizador. El espacio exterior, el mundo sensible es sicmpre transubjetivo para el poeta $y$, a veces, se encuentra en oposición frente al espacio íntimo, mundo de la conciencia.

In nuestro estudio sobre los espacios poéticos becquerianos partimos, pues, de la intimidad profunda a la extensión indefinida, reunidas en una misma "expansión", como diría Bachelard ${ }^{1}$.

1 Gaston Bacmirand, La poétique de l'espace. Paris, Presses Universitaires de Irauce, 1967, p. 183 . 
Pero antes de entrar en materia hemos de hacer una aclaración. $Y$ ésta es qué debemos leer a Bécquer con sensibilidad imaginante. No hemos de quedar adheridos a la simple objetividad, porque corremos el riesgo de leer sólo superficialmente. Hay que releerle en nuevos niveles y en nuevas direcciones de ensueño. Olvidemos un poco el lenguaje razonable y valgámonos del lenguaje figurado, sin el cual no es posible ni escribir verdadera poesía ni tampoco interpretarla: ondas de novedad circularán por la superficie de nuestro ser y nos revelarán un sentido constantemente abierto. Abrámonoos a nuevas, activas, èspejeantes sugestiones poéticas.

Releamos las Rimas no lineal, sino verticalmente: no siguiendo el hilo de lo que cuentan, sino hacia su fondo. Busquemos, primeramente, los 'espacios interiores' que aparecen en ellas y tratemos de: ver qué significan, qué nos sugieren, cómo funcionan. Veamos cómo. es :Bécruet por dentro - metafóricamente, claro-, antes de saber hasta qué punto el espacio exterior influye en su ser íntimo y en su creación poéticil. I'rocuremos indlagar algo de quiéll es cl mirante antes de saber algo de lo mirado por él, para penetrar, finalmente, en el sentido último de la dualidad que los constituye. La doble dimensión espacial ... con repeticiones de motivos y paralelismos estructurales - se destacará. como unn señero elẹmento unitario de esa colnerencia temática que buscamos en las Rimas.

\section{Los espacios interiores}

Para captar los espacios objetivos -y, con ellos, la presencia del cosmos y de las cosas - hay que nutrirse de espacio íntimo: de ese espacio que tiene su ser en nosotros. Ya lo decía Rainer María Rilke: "Por todos los seres se despliega el espacio único, el espacio íntimio en el mundo.... ${ }^{1}$ Luego - añadimos nosotros-, crecerán juntos, en doble sentido simbiótico de existencia real y de existencia poética. El alma del mundo se busca desde la propia, en emulación de grandeza.

Empecemos, pues, por el microcosmos de Bécquer. Partamos de su interioridad $y$, más que verlas, vivamos sus inágenes:

1 Loc. cit. Eil 'espacio intimo' es uno de los motivos poéticos más típicannente rilkeanos. En la segunda elegia de Duino, por ejemplo, menciona los respacios de la existenciar.- -Räume aus Wesen, (RAINIR MIARfa RuI,ke. Duino Elegies. With Euglish translation by C. F. MACINrYRE. Berkelcy, University of California Pres, I963. p. I3): respacios del ser". 
I. El espacio interior.-Bécquer intuye que éste existe de alguna manera, cuando siente - dentro de sí- un vago anhelo demiúrgico que invade su ser intimo: un ansia de elevarse, de flotar, de anegarse cul la luz.

$\therefore \quad \therefore \cdot$

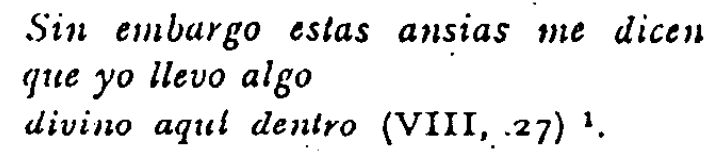

- Pero tal dimensión interior - valiosa en sí, pues es ontológica y representa la esencia misma del poeta y de su hombredad - no fue per cibila por la amada, según se ve en la rima XXXV:

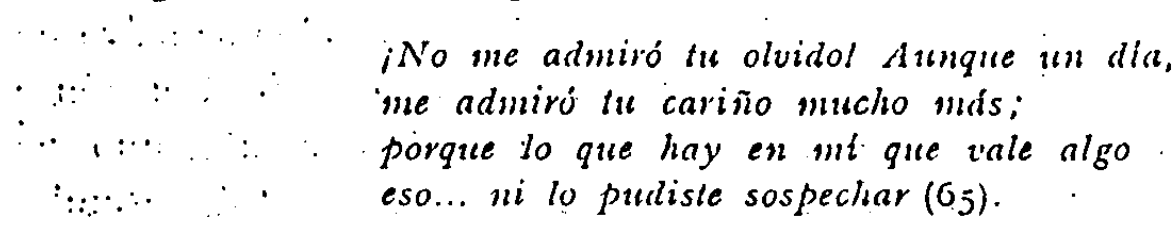

lise "algo" valioso se ha perdido en la nada del desamor, vaciándose su "spacio intimo?

Iil 'espacio interno' nutre los objetos de las Rimas, pues en él buscan sil allna: el cosinos entra en él y, al entrar, crece en él de nucvo.

2. El corazón ${ }^{3}$ - L a rima LVI, tan existencial - nacida en un moncuto de cansancio y de insensibilidad producida por la repetición del vivir cotidiano y habitual-, nos prueba que Bécquer distingue cutre corazón, inteligencia y alma:

- Búcleurr, Rimas. IElición, introducción y notas de Jusí Plivro Dinz. Madrid, : Espiasa-Calpe, 1968. Citaremos siempre por esta edición, indicando en-numeras, la rima y la página; la rima, en números romanos.

2 'l'al 'espacio interno' era para Rainer Maria Rilke -otro gran poetarese espacio que tiene su ser en tin, en un poema escrito en junio de 1924 , citado por I3ACHIi,ARD en La poétique de l'espace (p. I82).

3 Iin el esquema vertical del cuerpo humano, los puntos focales son tres: ccrclıro, corazón. y órganos sexuales. I'ero el punto central es el corazón y, en consecuencia, participa de los significados de los otros dos. Iil corazón cra la única parte de las visceras que dejaban a la momia los egipcios, porque lo consideraban como el centro indispensable del cuerpo en la eterniclad y en la vida de ultratumba. lorgue toxlos los centros son simbolo de eternidad, ya que el tiempo es la moción de la periferia de la rueda de los fenómenos rotando alrededor del aristotélico omotor inmóviln. Eín los sentidos tradicionales del pensamiento, era considerado la verdadera sede de la inteligencia, slendo el cerebro sólo su instrumento. Así, los antiguos vinculaban el sol al corazón y la luna al cerebro. la iuportancia del nuor en la doctrina mística de la unidad explica cómo el simbolo del anor está concctado con el símbolo del corazón, porque el amor es la única experiencia que urge al anante hacia un centro dado. Én la emblemática, el corazón significa amor como centro de iluminación y felicidad. (Cf.: J. L. Cintor. A Dictionary of Symbols. New York, I'hilosophical L,ibrary, I962, 1p. I3j-130.) 


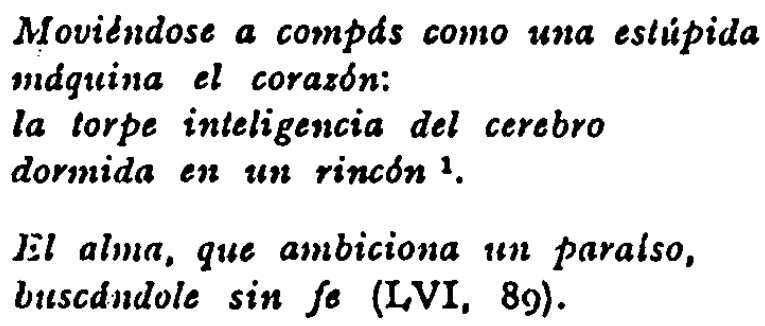

Aquí, el corazón es motor de vida, centro sensitivo fatigado de vivir, moviéndose mecánicamente porque es su costumbre. La inteligencia, a su vez, se ha dormido y no funciona: no rige los actos del vivir ni orienta la existencia. Sólo el alma vibra todavía: sólo en ella se salvan las últimas potencias de la vida - lo que se salvará, si algo se salva en el hombre, pues aún busca algo que está más allá de la fe. Corazón e inteligencia, en esta rima, parece que actúan sincrónicamente: uno, en su función psíquico-fisiológica; la otra, en su función mental, formuladora de ideas y de las direcciones del comportamiento humano. El alma, en cambio -aunque sostenida de algún modo por el corazón y la inteligencia-, actúa sola y aún se salva en ella algún resto de voluntad, con la esperanza de algo que se sabe alto y lejano, pero que no está segura de hallar. İs una fe escéptica la que la guía. Sólo ella trata de romper la monotonía del tiempo habitual, de lo que siempre es lo mismo, pues todo se repite 2: el vivir vegetativo, el andar; el tiempo de hoy, de ayer y de mañana.

En la rima LVII - también existencial como la anterior-, el pocta se siente envejecido por el dolor de vivir y el desamor, cuyas inequívocas señales se perciben no sólo en las arrugas de la frente, sino en su corazón, en el centro mismo de su vidá:

He envejecido, si ipese a mi estrella!
harto lo dice ya mi afdn doliente;
que hay dolor que al pasar, su horrible huella
graba en el corazón, si no en la frente (LVII, 9I).

Ėn opinión de Bécquer, el dolor moral afecta al vivir físico, al corazón y a la inteligencia.

Según la rima LXXX, el corazón no sólo es centro del vivir, sino el ámbito natural del amor. Al ser herido, toda la existencia es afectada. En estilo directo y de un modo muy dramático lo expresa el poeta en la rima XIVI s:

2 Nótese cómo el poeta espacializa metafóricamente la inteligencia a través de urincót" y tras vivificarla —dormida".

2 Adviértase el parcntesco con las ideas de Azorín.

- Esta rima pertenece a la seric del desengaño: XXX a IAI. 
Me ha herido recaldndose en las sombras, sellando con un beso su traición.

Los brazos me echó al cuello y por la espalda partióme a sangre fría el corazón (XLVI, 78).

Iil corazón de esta amada es entrevisto -en la rima XLVII-, más que como un centro psíquico, como un abismo hondo y negro (79), pues el poeta se ha asomado a él y ha detectado su inalcanzable trasfondo. Por traicionar o ser insensible al annor, deja de ser un verdadero corazón: una náquina, un órgano fisiológico, un espacio físico desprovisto de toda ulterior profundidad sensible: ha dejado de ser un noble espacio intimo para ser tan sólo una víscera, una máquina fisiológica:

Dices que tienes corazón, y sólo lo dices porque sientes sus latidos: eso no es corazón... es una mdquina que al compds que se inueve hace ruido (LXXVII, 125).

Bécquer utiliza como sinúnimo de 'corazón' la palabra 'entrañas', intrafondo de su vivir y de su amor:

Como se arranca el hierro de una herida su antor de las entrañas me arranque. aunque senll al hacerlo que la vida. me arrancaba con el (XLVIII, 80).

'Corazón' y 'entrañas' son espacios fisiológicos y también psíquicos, a los que viene a añadirse 'pecho'. Este aparece en la rima LXXXVIII, en la cual el poeta evoca un día de amor gozoso: a su espacio interior, vital y anímico, querría el poeta transferir su ser para refugiarse allí y salvarse del dolor:

soy yo, que en the pecho buscaba morada (1 38 ).

Y para el mismo pecho de Elisa escribió sus versos: las rimas buscaban cn él - simbióticamente con el poeta - un asilo de amor, ternura y sensibilidad:

para que llenen de emoción tu pecho

hice mis versos yo.

Para que encuentren en tu pecho asilo

$y$ les des juventud, vida y calor.

tres cosas que yo no puedo darles,

hice mis versos yo (IXXXV, 133). 
'Corazón' y 'pecho' son, pues, para Bécquer, sede del amor, del sentir y de un comprender vital y sensible: espacios no sólo fisiológicos, sino de profundidad anímica.

El corazón, finalmente, también es uno de los espacios de los que brota la poesía:

mientras el corazon y la cabeza

batallando prosigan,

- mientras haya esperanzas y recuerdos

; ihaurd poesia! (IV, I9).

3. La mente.-Según el diccionario de la Real Academia Española, la mente es "la potencia intelectual del alma". Pero esta definición no nos contenta en absoluto, pues, por lo menos, hay que establecer dos sentidos: I) La mente es el 'yo' o.sujeto que pércibe, recuerda, imagina, siente, concibe, razona, quiere, etc., radicando en el-cuerpo; 2) La mente es la sustancia metafísica que pervade todas las mentes individuales $y^{\prime}$ que se contrasta con la materia o sustancia material.

¿Qué es la mente para Bécquer? En la rima III, vemos que la mente es el espacio álgido, exaltado, por el que galopa el corcel sin freno de la inspiración poćtica:

Brillante rienda de oro

que poderosa enfrena

de la exallada mente

el volador corcel (III, 16).

Previamente, en la estrofa anterior, el poeta menciona el "cerebron como espacio internamente visible - aunque caótico- de la mente:

Giganle voz que el caos

ordena en el cerebro

$y$ entre las sombras nace

la luz aparecer (III, I 5).

Il cerebro, además, es el amplio espacio en que se fraguan las ideas:

Las ideas que en ronda silenciosa daban vueltas en torno a mi cerebro, poco a poco en su danza se movian... (LXXXI, ro8).

La mente es el espacio cn que se fabrican fantasmas, es decir, fantasías que suplantan los objetos verdaderos, que crean una irrealidad 
o realidad falsa: en este caso, el amor que aquí no es una realidad psíquica, sino una invención mental, un fdolo falso:

\author{
Dimos formas reales a una fantasma \\ de la mente ridicula invencion \\ $y$ hecho el tdolo y'a, sacrificamos \\ cn su allar nuestro amor $(\mathrm{I}, 82)$.
}

Scgún la rima IV, la mente - físicamente- radica en la cabeza y sc opone al corazón, sede del sentimiento:

$$
\begin{aligned}
& \text { mientras el corazón y la cabeza } \\
& \text { balallando prosigan } \\
& \text { jhabo poesia! (IV, Ig). }
\end{aligned}
$$

Son espacios y potencias en oposición que luchan y crean.

Bécefuer, al situar la mente en la cabeza, se revela como un monista, pues no la separa del cucrpo.

4: El pensar.-Como es sabido, el punto de partida del pensar procede de la expericncia sensible y está condicionado por el a priari psiculogico. l'ero es, sin embargo, un modo no sensible de:conocer, dirigido al ente cn cuanto tal y a las relaciones implicadas en su sentido ${ }^{1}$,

1. Iil pensar se realizạ en diversos actos de aprehensión (inteligencia de rejaciọn, formación del concepto, raciocinio) y de toma de posición (pregunta, duda, etc.) para llegar en el asentimiento del juicio al abrazo definitivo con un objcto. Pasa rítuicamente de la contemplación tranquila de un objeto (aprehendido.sea como fuere) al progreso y búsqueda de conocimientos siempre nuevos (pensar discursivo), y de entender en forma merameute reproductiva una verdad prescntada, entendiéndola mediante la comprensión de sus relaciones lógicas o verdades adquiridas en otra ocasión (pensar reproductivo), a un pensar creador más.judependiente (inspiración; intuición).

İl pensar se distingue esencialmente del conocimiento sensorial. No sólo se dirige a lo que cae bajo los sentidos, sino también a lo no intuitivo y en lo sensorialnente perceptible mira a la quididad (de quid, csencia, razóm, por qué de uua casa) de la cosa no aprehendible por aquéllos. Lin vez de seguir únicamente las lejes de las asociaciones y complejos que actúan de una mancra ciega para el centido (necesidad subjetiva del pensar), el pensar se orienta en último término por la conexión necesaria de los contenidos mismos (necesidad lógica "objetiva del pensar). A pesar de los diversos vinculos que le unen a lo material, wo es, como cl conocinicnto sensorial, una actividad inmediatamente co-ejecutada por la materia, sino que posee naturaleza espiritual. Apuntando al verdadero ser de lo chado y encontrado en él su objeto formal, puede, aunque a menudo sólo analósicamente, entrar en contacto con todo lo que de algún modo ticne que ser. Su awplitud cs, pues, ilimitada. Sin embargo, el pensar humano permanece prendido 
Para la Real Academia Española, 'pensar'. es, simplemente, imaginar, considerar o discurrir, reflexionar, examinar con cuidado una cosa para formar dictamen.

La acción de pensar y su efecto - lo pensado - es visible en la rima LXXIII, tras haber brotado en el ámbito de la sensibilidad y compasión becquerianas - su a priori psicológico-, y deviniendo así pensamiento coherente y lógico. Ha muerto una niña y, entre velas, sus restos están solos en la alcoba... Llega el nuevo día y despierta el pueblo con sus ruidos. Al poeta le duele este contraste. De su sensibilidad -hecha pensamiento- nacen estos versos, forma de su emoción:

\author{
Ante aquel contraste \\ de vida y misterio, \\ de luz y tiniebla, \\ yo perse un momento: \\ ¡Dios mito, qué solos \\ se quedan los mucrlosl (LXXIII, II3).
}

$Y$ el estribillo se repite dos veces más, al constatar la misma soledad de la niña muerta en la iglesia y en el cementerio. El pensar becqueriano, aqui, es meditación ante la muerte y formulación lógica de lo que siente en el alma.

de muchas maneras en la unidad psiquico-somática del conocimiento sensible (y. por lo misino, a lo material e inconsciente), tanto en los actos de aprehender como de tomar posición. Ios contenidos de nuestros conceptos proceden casi todos de la experiencia sensible. Toda comprensión más o menos compleja de datos y todo pensar creador de algo nuevo se sirven de complejos inconscientes, lo cual frecuentemente ocurre en tal medida que las intuiciones" creadoras e sinspiraciones pueden aparecer casi como obra de lo inconsciente. Sin embargo, estos procesos inconscientes no son verdadero pensar; el trabajo intelectual productivo se consuma por la cousciente inteligencia de relación de conexiones intelectuales dotadas de sentido.

Nuestro pensar está uiterionmente condicionado por el "a priori psicológico", en cuanto que las particularidades tipicas o accidentales del stemperamento intelectualn, la peculiaridad de los contenidos de peusanientos adquiridos y acostumbrados (a los cuales ha de incorporarse lógicamente lo que va a entenderse por primera vez) influyen (a veces imperceptiblemente) tauto sobre los procesos de elaboración discursiva de conocimientos como sobre la configuración de sus contenidos. También influye el estilo de personalidad humana del que piensa, y el ethos incondicional de la verdad.

Según Kant el peusar se opone al conocer.

(Cf. Walter Brugger, Diccionario de Filosofia. Barcelona, Herder, 1962, pp. $360-362$.) 
El pensamiento - acción y efecto del pensar - se introduce en otras rimas, revelando en todas la misma connotación: expresar lógicamente lo sentido por el poeta. En la rima XXXV, Bécquer regalaria, precisamente, esta facultad de pensar y de trasmutar en poesía cuanto vive, sólo por tener dormida sobre su pecho la cabeza de la amada, sólo por lograr leer lo que ella piensa, en doble trueque amoroso:

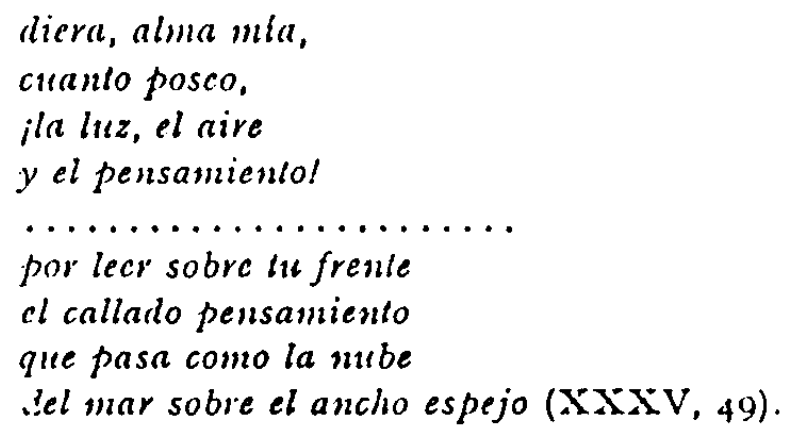

Iil annor, por último, tiene la facultad de alejar las penas del pensar, pues aquél declara:

alcjo los pesares del pensamienlo (IXXXVII, 137).

Uil pensar, por tanto, es la forma -espacio lógico- en que se expresa la sensibilidad interior -amorosa o doliente-, los estados del alma sensible. Pero, además, es la potencia que permite al poeta penetrar los misterios del cosmos, traspasar el más allá de la realidad, que acaso sca la nada:

Yo me he asomado a las profundas simas

de la tierra y el cielo,

$y$ les he visto el fin, o con los ojos

o con el perisamiento (XLVII, 79).

La meditación ante la vida y el amor, ante el cosmos y su finalidad, lleva a veces al poeta a la duda: su ánimo y su pensamiento se suspenden ante ellos $y$, vacilante, el pensar formula su juicio. Bécquer - hombre sensible- $n o$ entiende $\mathrm{y}$ así dice en otra rima:

In el mar de la duda en que bogo ni aín sé lo que creo (VIII, 27).

Sólo la razón puede destruir la duda, dar sentido a los pensanientos ordenándolos lógicamente:

Itilo de luz que en haces

los pensamientos ata... (III, I6). 
5. Las ideas.-Etimológicamente, 'idea' (18єiv) significa 'ver' y así es: r) el aspecto manifiesto de una cosa según sus rasgos caracteristicos - es decir, es simple conocimiento de ella-, y 2) designa el aspecto interior o contenido esencial en que aquél se revela. Mientras que el concepto sigue al ser de las cosas y reproduce su esencia, la idea le precede como eterno y perfecto arquetipo, conforme al cual han sido ellas configuradas. La idea es, por tanto, cansa ejemplar o arquetípica. Aprehendida por el entendimiento, conviértese en norma (canon), con arreglo a la cual éste juzga las cosas que se le presentan o se guía en la realización de la idea ${ }^{1}$.

¿Qué son las ideas para Bécquer? ¿Cómo se manifiestan o aparecen en las Rimas?

En la III, las ideas son mencionadas en la primera estrofa para indicar que -al crear poesía- la inspiración ha de operar con ellas y sobre ellas, agitándolas, revolviéndolas, sacándolas a vida desde el espacio inmaterial de la mente:

\section{Sacudimiento extraño que agita las ideas como huracdn que empuja \\ las olas en tropel (III, 14).}

La inspiración, en ráfagas, les dará aliento vital, las pondrá a vivir, a sentir, sin que pueda darles la forma, el vestido de la palabra - la expresión lógica o poética:
Ideas sin palabras, palabras sin sentido, cadencias que no tienen ni rilmo ni compds (I5).

Sólo la razón puede imponerles orden y darles sentido, estableciendo asociaciones, paralelismos, agrupándolas en categorías de semejanza o disparidad, etc.:

$$
\begin{aligned}
& \text { Almósfera en que giran } \\
& \text { con orden las ideas } \\
& \text { cual dtomos que agrupa } \\
& \text { recondita atracción... (10). }
\end{aligned}
$$

1 Como es sabido, I'latón considera las ideas como realidades independientes supramundanas que representan un reino propio bajo la idea suprema del bien. Plotino y San Agustin las convierten en los pensamientos originarios creadores existentes ell la mente divina. Dios mismo es la Idea absoluta o Idea de las ideas en cuanto que su infinita plenitud abarca todas las esencias en altisimo desplieguc. Santo Tomás - siguiendo a Aristóteles- llegó a la abstracción de las ideas partiendo de las cosas. 
En la primera estrofa de la rima $\mathrm{V}$-en la cual Bécquer define qué es la Poesía para él-, ésta vive "con la vida sin formas de la idea" (20). La Poesia, finalmente, aspiratá -en la penúltima estrofa- a lograr la fusión perfecta de idea y forma:

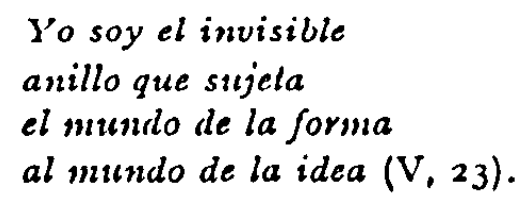

'lodo poema, en consecuencia, contiene una idea y ésta constituye su fondo, su espacio y sentido interior, contenido por la forma externa, hecha de ritmos y palabras.

En la rima XIII, Bécquer parece conceder cierta espacialidad - hecha de luz, de inteligencia - a la idea, tocada por el amor:

Tu pupila es azul y si en su fondo
como un punto de liz radia una idea
me parece en el cielo de la tarde
una perdida estrella (XIII, 35).

Lin la XXIV, las ideas se vinculan a las almas enamoradas, al nacer al mismo tiempo en la mente creadora, y poseen la capacidad de unificarse sincrónicamente al estar unidas por una relación de simpatía o amor:

Dos ideas que al par brotan

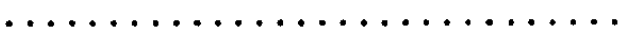

esas son nuestras dos almas (XXIV, ${ }^{8}$ ).

Ein la LXXI - en donde Bécquer evoca esa atmósfera poéticamente visionaria en que presiente la muerte de alguien a quien ha querido (atmósfera de la vigilia anterior al sueño)-, las ideas se concretizan y hasta se corporizan al danzar rítmicamente en el espacio del cerebro:

Las ideas que en ronda silenciosa daban vuellas en torno a mi cerebro, poco a poco en danza se movian con un compds más lento (LXXI, I08).

6. La razón.-La 'inteligencia' -esa facultad de conocer y entender - es mencionada en las Rimas - en la LVI - sólo una vez. En otra - la III-, Bécquer usa el adjetivo "inteligente" para aplicarlo a la 
razón que da sentido, orden y ritmo a las palabras que constituirán el poema:

\author{
Inteligente mano \\ que en un collar de perlas \\ consigue las indóciles \\ palabras reunir... (III, 16).
}

La 'inteligencia', acaso, le parece al poeta demasiado abarcadora, puesto que es la capacidad de la mente que comprende - a través de la memoria, de la imaginación y del pensar conceptual - los problemas teoréticos y prácticos con los que se confronta. Iin sus poemas, esas vías o instrumentos de la inteligencia se muestran separadamente. La 'razón', en cambio, es mencionada varias veces en las Rimas, constituyendo uno de sus temas más significativos.

Según la opinión vulgar, 'la razón' es la facultad y el acto de discurrir. En sentido lato, es la facultad cognoscitiva intelectual en oposición a la sensibilidad: es, pues, sinónimo de entendimiento. Sin embargo, a veces existe una oposición entre estos dos modos de activiclad mental. Lin general, 'entendimiento' significa preferentemente el pensar que abstrae, compara y descompone; y 'razón' designa la actividad intelectual superior que tiende a la conexión y unidad definitiva del saber $y$ del obrar ${ }^{1}$.

¿Qué es la 'razón' para nuestro poeta? En la rima III - construida sobre la dualidad inspiración-razón-, ésta es el poder ordenador que sabe refrenar, atar, reunir con inteligencia, armonizar, modelar con belleza, vigorizar el espiritu y calmar, al mismo tiempo, la sed interior:

\author{
Gigante voz que el caos \\ ordena en el cerebro \\ y entre las sombras hace \\ la luz aparecer, \\ Brillante rienda de oro \\ que poderosa enfrena \\ de la exallada mente \\ el volador corcel, \\ Hilo de luz que en haces \\ los pensamientos ala.
}

1 I a 'razón', pues, es la facultad del peusar discursivo, característico del cutendimiento humano abstractivo. Para Kant, el entendiniento es la facultad de los conceptos y juicios: la razón, en sentido estricto, es la facultad del raciocinio $y$, por lo tanto, de buscar lo incondicionado para lo condicionado. La razón es inferior al entendimiento en valor cognoscitivo. 


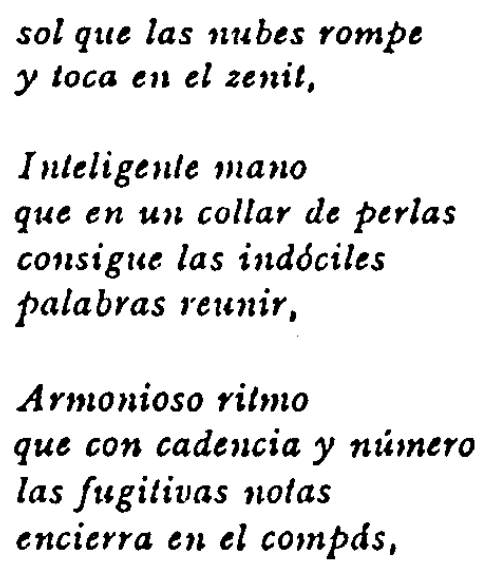

Tal es muestra razon (III, I 5-I 7).

Lista es -según Bécquer- esencial en la transmutación poética, pero no es toda ella, puesto que la inspiración le suministra los materiales sobre los cuales ha de operar. Poéticamente, según esta rima, 'la razón' es espacial porque se da en el cerebro y, metafóricamente, se concretiza en "rienda", en "hilo de luz», en "mano", en "cincel», en "raudal", en "oasis». La razón, en poesia, es identificable por imágenes visibles.

7. El alma.-José Pedro Díaz -en su excelente libro sobre la vida y la poesía de Bécquer- ${ }^{1}$ se ha referido muy brevemente al alma becqueriana y sólo en relación con el movimiento de la imaginación ${ }^{2}$, scñalando su dinámica ascendente en cuanto al amor y en cuanto a la poesfa, y su paralización — «detención»-3 por el dolor. Nás adelante

1 Joski Pedro Dinz, Gustavo Adolfo Bécquer. Vida y poesia. Madrid, Gredos, 1964 .

Ibid., pp. 408-410.

- Ibid., p. $4^{\text {IO. }}$

7 
nos habla del "trasmundo espiritual" 1 becqueriano, pero nunca llega a precisarnos qué sea el alma de Bécquer, configurada por las Rimas, trascendida desde ellas. Tal es nuestro propósito: aunque jamás lleguemos a definirla por completo, procuraremos asediarla para captar ciertos peculiares matices $y$, sobre todo, su 'espacialidad', su ámbito intimista.

Iil más ingenuo lector de las Rimas sabe que 'el alma' es palabra clave dentro de ellas, en su.metaforismo y en su semántica poética, aunque no haya podido clarificar ni el cómo ni el por qué. Esa es la tarea que nos hemos propuesto, sin que aspiremos a una explicación léxica del término ni a hacer un estudio psicológico de sus variados usos. sólo aspiramos a adentrarnos de alguna manera en el espacio animico de las Rimas, en el sentido de lo que 'el alma' significa dentro de ellas, y cómo se manifiesta o aparece en sus versos, diseñando - cuanclo sea posible - su 'espacialidad' íntima al actuar como dintorno del ser. Aliora bien, no nos confundanos: al referirnos al alma como un 'espacio' existente, jamás abstracto, aludimos a un espacio inmaterial, en cuanto ella es una sustancia simple que permanece a través de los cambios de los procesos vitales, que produce y sostiene las actividades de la vida psíquica y que vivifica el organismo ${ }^{2}$.

'Todo el mundo sabe, además, que el espacio es tridimensional: I) que hay un espacio matemático -cuya extensión es abstracta, geométrica; 2) que hay un espacio físico - que es la extensión real de las cosas, y 3) que hay un espacio curvo, que es la extensión de la luz en el campo gravitatorio del universo.

Por nuestra parte, nosotros imaginamos una cuarta dimensión del espacio: la poélica. Y este espacio antmico es aprehensible, mensurable, visible, audible -en términos poéticos, claro-, sólo por los movimientos reacciones y corportamientos del alma.

La percepción del espacio tridimensional nos la procuran, principalmente, la vista, el tacto, los sentidos estático y cinestésico y el intelecto. La percepción del 'espacio animico' sólo es perceptible poéticamente.

Sería inútil e interminable recoger aquí -recorriendo toda la historia de la Filosofía - el índice completo, o más o menos completo, de lo que ha significado el alma para los filósofos.

I Ibid., p. 4 ig.

2 l'ara nosotros esto quiere decir que si el alma es sustancia - -ser; esencia, 'lo que estíl dehajo'-, ocupa un espacio, es un espacio; pero, cómo es inmaterial, este espacio también lo es. 
Contentémonos, de momento, con nuestra propia interpretación. Según, ésta, el alma - considerada espacialmente - se acercaría al espacio homogéneo $y$, al mismo tiempo, representaría un omniverso no sólo cuatridimensional, sino también absolutamente original, inédito, en su subjetividad, en su intimismo poético.

Iil alma de Bécquer - a pesar de su hondura lírica, de su autenticidad tan personal - no es en ningún modo solipsista, sino que se abre al mundo, al amor y al dolor. Para el poeta, la totalidad de la realidad, del universo y de las personas - representadas por sus amadas mayormente - no son representaciones de su ser, sino que tienen existencia independiente, pero que le afectan de manera profunda y que presionan sobre su sensible intimidad, alterando a veces el temple de su alma, su esparcialidad anfinica, su total realidad interior, la esencia misma de su psy'che.

La palabra 'alma' se destaca señera en la rima I:

Yo sé un himno gigante y extraño
que antucia en la noche del alma una aurora (I, I I). 1

a) Espacio de la misica.-Eil alma, aquí, es una realidad espacial en la que transcurre el tiempo interior despertado por la realidad melódica de la música ${ }^{2}$. Ė alma no sólo capta cromáticamente el claroscuro de la pena y de la alegría - "noche» y "aurora»--, sino que aprehende la realidad acústica - temporal- de la música hecha "himno" en la rima. 'Tal realidad espacio-temporal es prueba de la finísima receptividad cmotiva del poeta: música y color entran en el ámbito del alma y se identifican con su esencia.

Iin la rima III vuelve el alma a ser recinto, espacio interior de la música:

$$
\begin{aligned}
& \text { Murmullo que en el alma } \\
& \text { se eleva y va creciendo (III, I4). }
\end{aligned}
$$

La temporalidad de la música no fluye externamente de la sensación acústica, sino que, interiorizada en el espacio anímico, sólo en él se eleva y crece $y$, así, parece brotar del alma, su verdadero reino. El espacio anímico becqueriano carece, aquí, de peso estático y por eso fluye, elevándose dinámica y nusicalmente.

1 De hecho, es el primer 'espacio interior' que penetra en nuestra alma.

- l'ara Rilke, la música es "cspacio del corazón", lo mis intimo que, rebasándonos, se lanza afuera y, entonces, to interior nos rodea / como la más /amiliar lonlananza, como / el reverso del aire, / puro, inmenso, / no habilable yan. (Cf. RAINiR Mlaria Rir,ki, Poesía. 'Traducción de Dorotlia I'atkicia Latz. Barcelona, Yun(ue, 1939, p. 87). 
En la rima XXVIII, el tiempo se inserta en el espacio interior y el alma deviene ámbito de una música lejana y dulce:

Cuando en la sombra oscura
perdida una voz murmura
turbando su triste calma.
si en el fondo de mi alma
la oigo dulce resonar:
Dime: i Es que el viento en sus giros
se queja, o que tus suspiros
me hablan de amor al pasar? (XXVIII, 55).

Es la música amorosa que espera oir siempre el alma enamorada, aunque el viento la disfrace en el espacio interior, en el cosmos de la intimidad.

b) Espacio del annor y de la poesia.-En el alma becqueriana no liay claros deslindes entre el amor y la poesía, pues ambas coexisten simbióticamente. Muchas rimas, más que entrelazarlos, los entretejen cn una misma urdimbre anímica, unificados en el espacio y en el tiempo de una misma intimiclad.

Ein la rima IV, animado por el amor, el espacio anínico becqueriano, proyectándose activa y dinámicamente hacia fuera, trasciende fervor amoroso, esencia misma del milagro poético:

Mientras se sienla que se ria el alma, sin que los labios rlan;

ilhabrd poesia! (IV, 19$)$.

Iil alma, transfigurada por el amor, vuélvese presencia visible, corpórea o transcorpórea, y su alegría trasciende al poema, en el cual quedan, unificadas por el beso, las almas de los dos amantes:

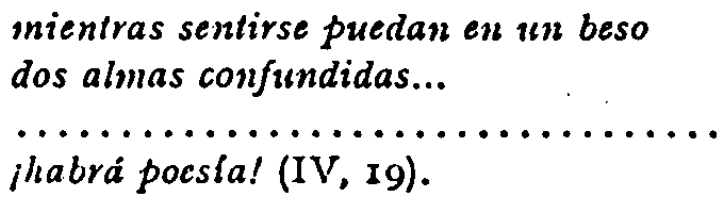

En la rima XXVII, la amada es alma del alma enamorada, su más intima esencia, centro mismo de su espacio interior, de su verdadera realidad: centro de su centro. En consecuencia, la poesía emana de la amada, centro del ser y del existir:

Dormida, en el murmullo de tu aliento

acompasado y tenue,

escucho yo un poema que mi alma

cuamorada entiende (XXVII, 53). 
I a amada es poesía, crea poesía y dicta a su amante sus rimas de amor.

Pero en la estrofa última de la $\mathrm{LXXXV}$, dedicada a Elisa Guillén, el pocta declara que su alma - con todo lo que ha amado, soñado y sufrido- es la materia viva de su poesía y todo su espacio interior y psiquico:

Para poder poner anle tus plantas la ofrenda de mi vida $y$ de mi amor. con alma, sueños rolos, risas, lágrimas, jhice mis versos yol (I.XXXV, 133).

Iin otras rimas, sin embargo, el amor es materia única. En la $\mathrm{XX}$, el aluna trasciende al exterior su sentiniento amoroso a través de la mirada $y$, dinámicamente, se vierte en el beso y arde:

\author{
Sabe si alguna vez tus labios rojus \\ quema invisible atmósfera abrasada \\ que el alma que hablar puede con los ojos \\ tambien pucde besar con la mirada $(\mathrm{XX}, 43)$.
}

Lin la rima $\mathrm{XXIV}$, las almas de los annantes - al trascender al universo- unifican el espacio y el tiempo, los objetos temporales y espaciales: dos llamas de fuego "forman una sola llama", dos notas se confunden cn una sola al sonar en el laúd al mismo tiempo, dos olas mucren juntas en la playa, dos jirones de vapor se unen en el cielo en una nube blanca.

\author{
Dos ideas que al par brolan, \\ dos besos que a un tiempo estallan, \\ dos ecos que se confunden, \\ eso son muestras dos almas (XXIV, 48).
}

Lo dual se hace uno cuando el amor trasciende, pues éste niega toda separación, toda dualidad. El alma se hace visible y audible en el espacio $y$ en el tiempo exteriores cuando el amor la unifica con otra: las imágenes del mundo traslucen, entonces, realidades íntimas, la suprema rcalidad del amor. Lo de fuera es traducción o fiel reflejo de lo de dentro. $Y$ así, el alma arde, suena, rompe como ola, se hace vapor y asciende: cs idea, beso y eco, confundida con otra alma enamorada que, a su vez, coexiste unificada en el arder, el sonar, el ascender, etc. Lal espacio interior se amplía, se intensifica, se redobla: crea más espacio, otro espacio que es una continuación de él mismo. 
En la rima $X X V$, el alma de la amada se confunde con la del poeta, en la maravillosa simbiosis psíquica del amor. $Y$ por poseer el alma -el espacio interior, dimensión verdadera de la que ama-, el poeta, en suprema generosidad, claría cuanto posec y.es.y hasta el espacio exterior en que vive:

la lisz, el aire,

y el pensamiento (XXV, 49).

Daria todo lo de aquí y, además, todo lo que está más allá, suprasensible:

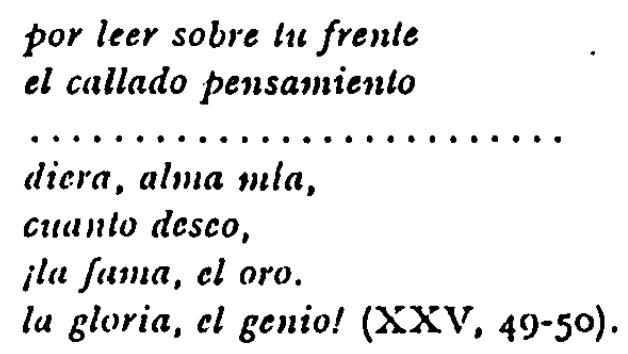

Iil alma del poeta renuncia a todo porque sólo aspira a vivir en el espacio interior de la amada, micro y macrocosmos psíquico:

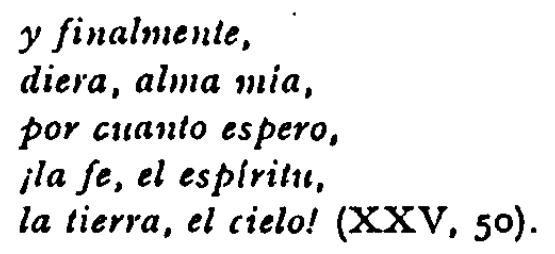

En la rima XXVIII, el alma del poeta ve a la que ama en el cosmos $y$ dentro del tiempo exterior. El espacio íntimo, volitivo, dinámico, proyecta su anhelo amoroso a la inmensidad del tiempo y del universo $y$, en ellos, "ve" o "cree ver" a la amada. Y la desea no con su cuerpo, sino con su alma, porque es lo más noble de su ser, centro de su existir. El deseo se espiritualiza, pero no por ello es menos ardiente y menos real:

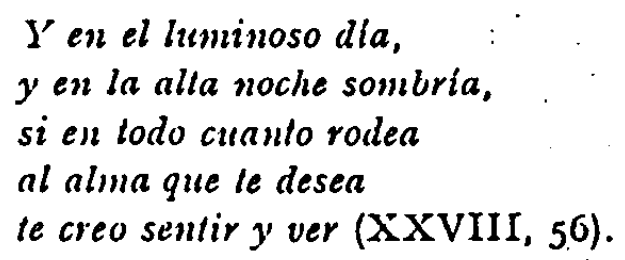

Lì alma lia dilatado su centro y el de la que ama, proyectándolos, transfiriéndolos al espacio cósmico, con sus días y sus noclies. 
Lún otro momento, el anhelo del enamorado - más del espíritu que de la carne- penetra el alma de la amada, como si ella fuera su refugio, el recinto y el huerto del amor:

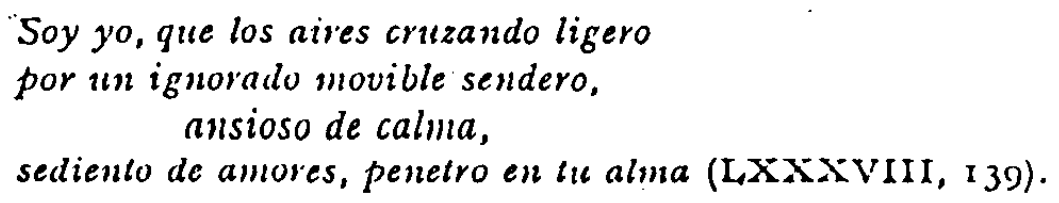

Iil alma ha rebasado sus muros - los límites corpóreos-y penetra ell el cercado anímico de la amada, buscando reposo. Los espacios interiores se confunden y el alma enamorada calma su sed, vivifica su centro.

c) Espacio del desamor.-Cuando éste adviene -y no precisamente por falta de amor en el poeta-, el espacio anímico se hiela, se cnvenena, se desgarra, se insensibiliza.

Iin la rima titulada El amor, éste, personificado, se autodefine: es rayo, es "dulce brisa" y, sobre todo, es "poder que abrasa un alma helada" (137). Bécquer afirma aquí que, sin amor, el espacio intimo del hombre es un desierto de hielo, un país desolado e invisible.

Ein la rima LXXXIX, el poeta hace una sintesis de la doble historia amorosa de su vida y cuyo fin ha sido tener conciencia de su amarga ponzoña:

Una mujer me ha envenenado el alma, otra mujer me ha envenenado el cuerpo... (LXXXIX, 127).

Bécquer no recrimina a ninguna, pues ha aceptado su destino doloroso, pero sí constata que el espacio de su alma es reino emponzoñado, incapaz de libertarse y de ascender, incapaz - quizá- de volver a amar, a ser en plenitud. El veneno ha llegado hasta el centro del alma y la ha anicyuilado y corroído.

In la rima LXVI, Bécquer se enfrenta con su destino y se pregunta de dónde viene y a dónde va. Iil amor era su norte y su finalidad. Sin él, sólo le aguarda el camino de la tumba, solitaria, sin losa, en "londe habite el olvido" (103). Y, en este caminar doloroso hacia la soledad de la muerte, el alma -identificacla con el cuerpo, tangible, pero aún viva por doliente- irá desgarrándose poco a poco. El alma y la vida -dramáticamente unificadas y concretizadas- viven hacia atrás todo el dolor sufrido, todo el desamor, en estos versos de trágica vivacidad:

Los despojos de un alma hecha jirones

en las zarzas agulas, 
Le dirdn el camino

que conduce a mi cuna (LXVI, ro3).

El alma ha salido de su interioridad, pero, esta vez, ha sido para desgarrarse y morir con el cuerpo al que vivificaba intimamente. El amor ha destruido el alma, su espacio musical, su reino de pocsla, su impulso dinámico y creador.

Si el amor sensibilizaba el alma hasta el punto de hacerla trascender al exterior, prolongando su ámbito, dilatando su centro hasta invadir el mundo, el desdén amoroso la vuelve un espacio insensible, la endurece, la vacía. Es el alma de Galatea, la mujer desdeñosa. Es İlisa Guillén - ¿o Julia Espin?-, en la rima XXXIX:

es allanera y vana y caprichosa:

antes que el sentimiento de su alma, brotard el agua de la estéril roca (70).

En la rima XIII, Bécquer alude al terrible monento en que tuvo noticia de la traición de Casta Esteban, su mujer. La intensidad de su dolor produjo en él la pérdida de la conciencia espacial: "la concicncia perdi de donde estaba" (74) -nos dice-. Pero, en cambio, su alma se volvió espacio de la contradicción psíquica y existencial:

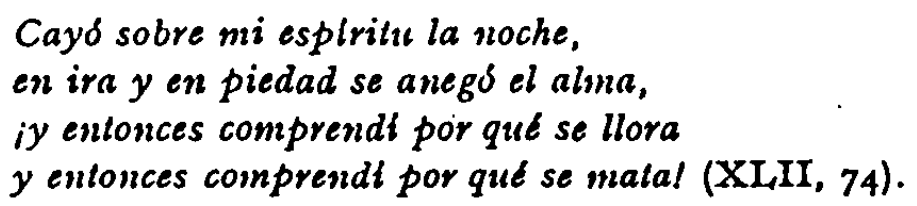

En la rima XLVII, el espacio del alma se dinamifica para traspasar la realidad psíquica y la realidad del universo. El poeta se asoma a las simas del mundo y, con los ojos o con el pensamiento, puede verles el fin. Pero se ha asomado al fondo de un corazón -el de la amada pérfida- y su alma se ha conturbado, porque en aquel espacio interior sólo vio el vacío de la nada:

\section{Mas jay! de un corazbn llegué al abismo $y$ me incliné un momento, y mi alma $y$ mis ojos se turbaron: \\ iTan hondo era y lan negrol (XLVII, 79).}

El alma del poeta ha transferido su propia oquedad interior - vaciada de toda luz por el engaño de la esposa adúltera - el alma de ésta. El desamor ha creado ahora una simbiosis de sombra, de vacío existencial. El espacio del alma traicionada es un negro abismo: la imagen de la nada. 
In la rina LVI, el alma del poeta -anestesiada por el constante paso del tiempo, insensible al dolor, en la eternidad de lo habitualanhcla un cielo, un mañana mejor, pero los busca sin fe -perdida al perder el anor-: quiere creer sin creer. El espacio interior se mueve hacia otro espacio lejano y alto, sin saber en dónde está ni qué es, pero en donde ansia, acaso, reencontrar el amor, su dios perdido. Religiosa y agnústica, a la par, el alma - coufundida con el ser y el existirarrastra la monotonía del vivir cotidiano y aspira intimamente a un paraíso perdido:

\section{El alma que ambiciona "un paraiso,} buscdndole sin fe (LVI, 89).

d) Espacio del dolor.-Desterrado el amor de su reino, el alma ya es sólo espacio doloroso, ámbito de la tristeza.

Lin la primera estrofa de la rima I,XII, Bécquer nos describe el momento en que nace la aurora sobre el mar. In la segunda y última nos explica el significado de sus símbolos psíquico-temporales para terminar afirmando que su alma es espacio y reino del dolor. P'ero aún aspira, aunque vagamente, a la luz, a la dicha de un nuevo amanecer. ¿Lil del amor o el de la muerte?

\section{La brilladora lutmbre es la alegria, la temerosa sombra es el pesar: ¡Ay!, en la oscura noche de mi alma ¿cudndo amanecerd? (LXII, 98).}

Isspacio y tiempo, en el alma triste, se confunden en noche cerrada, sellada en sombra por el dolor. ¿Habrá aún una nueva aurora?

e) Espacio de la muerte.-Al final de la célebre rima LXXIII, y después de manifestar su piedad profunda por los muertos -eternamente solos-, Bécquer se formula las más graves preguntas sin respuesta:

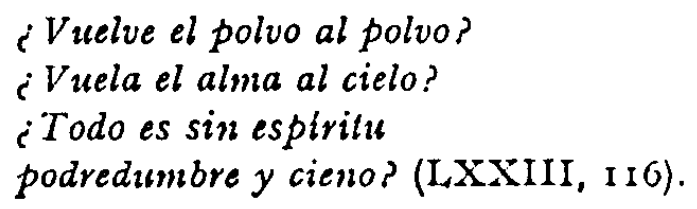

lin otras palabras: ¿vive el alma tras la muerte, sin el espacio físico que la contenía? ¿Se ha de liberar de éste para devolverse a su patria, al espacio puro y sin muerte? El poeta no puede responder a tales incógnitas, pero sí sabe con certeza que le duele la soledad triste de los mucrtos. ¿I a soledad del alma hecha ya espacio de la muerte? 
En la rima LXXVI, dentro de un templo bizantino, Bécquer evoca la tumba de una mujer hermosa..Y, al ir contemplándola, el verso - más que dibujar - casi va modelando escultóricamente el cuerpo, el rostro, la somrisa última de la que no parece muerta, salvada por el arte. Al final, casi en éxtasis ante "aquel lecho de piedra" (122), el espacio y el tiempo se cruzan ante el poeta y su alma siente el ansia de vivir toda la eternidad en la muerte, de absorber todos los siglos pasados, suspendidos en un instante:

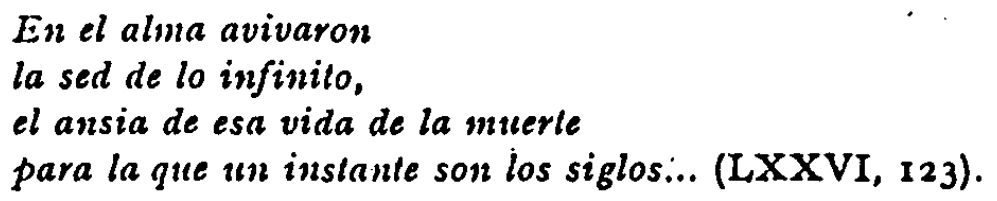

El alma desea aniquilar su propio espacio y hacerse espacio de la muerte tranquila: espacio de ese otro amor callado que es el morir.

f) Espacio de la luz.-Lin la rima LXXI, Bécquer entrevé el alma como un espacio interior en que reina la luz de las visiones oníricas: no es la que viene de fuera, sino que brota de los propios centros de la mis honda psyche. Y esta luz interior crea todo un mundo visionario, sueños puros, en la vigilia del sueño físico, en la frontera del dormir.

\title{
De la luz que entra en el alma por los ojos los parpados velaban el reflejo: mis olva litz el mundo de visiones alutmbraba por dentro (LXXI, 108).
}

Lil oscuro espacio del alma sin amor ha sabido crear la nueva luz de la visión onírica.

g) Espacio onirico.-En la rima LXXIV, el poeta acierta a precisar una visión onírica en que el amor y la muerte parecen confundirse en la imagen "confusa $y$ " blanca" (II7) detrás de la verja guardada por clos ángeles. Y a entreverla así, mitad luz, mitad sombra, el alma se le vuelve espacio del deseo: se concreta en voluntad que le impulsa a penetrar los hierros, a ingresar en lo desconocido, atraído por aquella presencia de amor y muerte que sólo podrá ser vista o posefda cuando Dios quiera:

\author{
La vi como la imagen \\ que en leve ensueño pasa, \\ como rayo de luz tenue $y$ difuso \\ que entie tinieblas nada. \\ Me senll de "ln ardienle \\ deseo llena el alma;
}




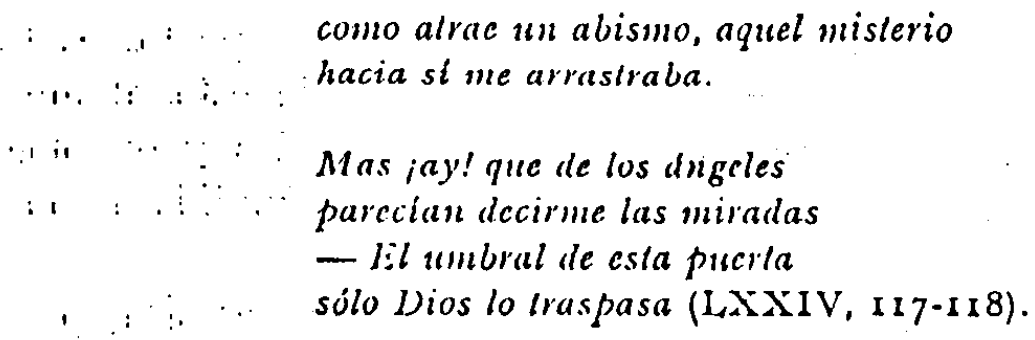

11) Espacio interior de otra alma.-In la rima LXX, Bécquer nos habla de su tristeza describiendo líricamente diversos momentos temporales. Se ve a sí mismo externamente, como una "triste tumba" que amedrenta a los que encuentra $y$, así, su alma deviene un alma en pena: espacio interior de otra alma, espacio de pecados no cometidos, espacio de ultratumba:

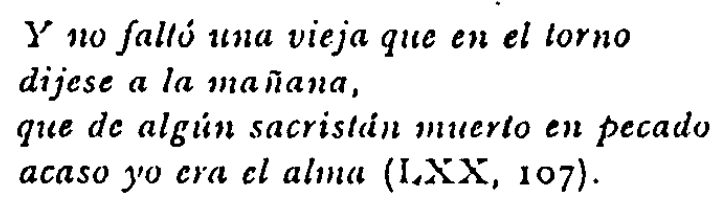

i) Espacio del genio; espacio de la gloria.- En la rima VII, al contemplar el arpa en silencio y cubierta de polvo, Bécquer se reficre al alma como un hondo espacio en donde duerme el genio esperando la la voz de la inspiración: ésta le revelará de nuevo, al vibrar, la música poética:

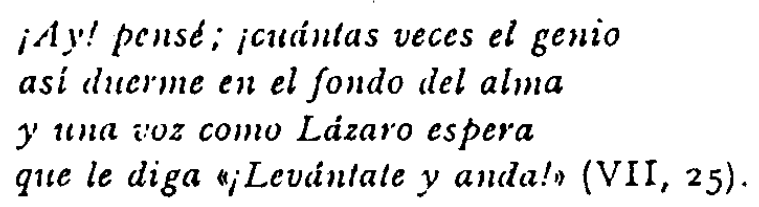

Iin la rima LXXII -construida musicalmente con tres roces-, la primera representa al alma poseída por el amor. En la segunda, en cambio, el alma es anhelo y espacio de la Gloria: "nubc radiosa", "isla dc sueños) (IIO).

Li alma es -entre los espacios interiores que habitan las Rimasbásico y primordial, pues a ella se subordinan el espíritu y la mente, la razón y la imaginación. İl alma es materia psíquica y espacio interior de la creatividad poética. Y las Rimas son la alegoría de un alma - la de Bécquer- en sus ascensos, vacilaciones, derrotas y caídas. Eil alma 
ha absorbido totalmente la persona del hombre y del poeta: es toda su interioridad $y$, al mismo tiempo, la proyección de ésta al mundo exterior. El alma, así, enriquece el contenido metafísico y psicológico de las Rimas: es la psyque de la filosofla platónica infundida a todo el ser del poeta.

Etica y filosóficamente, el alma becqueriana no es estoica; porque el estoicisno advierte que la felicidad puede obtenerse tan sólo si se desechan las preocupaciones y las molestias del vivir. Bécquer, por el contrario, ni careció de ansiedad anímica ni de molestias corporales, ni tampoco supo vencerlas: pero pudo salvarse - aunque muy parcialmente- en la visión onírica, en el ensueño romántico. .

En las Rinnas, el alma es signo metafórico, ideológico y estilistico, a la par, compendiando uno de sus valores fundamentales: penetrar en la intimidad del poeta, en la intimidad del hombre. Las Rimas constituyen, sf, un libro de introspección, a veces dulce, a veces tormentoso.

Finalmente, Bécquer afirma en sus Rimas la cognoscibilidad del alma por medio del amor, y éste es el verdadcro principio vital, el animador de la vida, el creador de la poesía. Alma y amor están unidos por una relación óntica. Lil alma es centro de la conciencia, pero ella se apaga si el amor no la estimula. Sin amor, la vida pierde su dignidad y su sentido, destruye su nobleza; el alma pierde su luz y se convierte en una oquedad que configura la nada. La poesía se extingue, seca sus fuentes. Si acaso sobrevive es porque, a veces, el alma - queriendo salvarse - crea en su ámbito visiones oníricas en que el recuerdo de la amada se confunde con la muerte, el fin con el principio, la noche con la aurora.

8. La memoria.-Obviamente, es la potencia del alma por medio de la cual se retiene y recuerda lo pasado. Es psicológicamente analizable en tres funciones: I) reproducción de la imagen; 2) reconocimiento de la imagen perteneciendo al pasado del objeto recordado; 3) localización temporal del objeto recordado por referencia a un esquema psíquico o físico temporal.

Todo el mundo sabe también que hay dos clases de memoria: I) la memoria sensitiva, cuyas imágenes son representaciones sensoriales y en la cual hay una participación psíquica ligada a una excitación corporal determinada; 2) la memoria intelectual o saber latente, relativo, que reproduce: a) proposiciones geométricas aprendidas, y b) actos espirituales propios del entendimiento y de la voluntad y que se someten a examen para una más rápida y exacta comprensión.

¿Qué es y cómo funciona la menoria en las Rimas de Bécquer?

El poeta le confiere poéticamente cierta espacialidad, pues se re- 
fiere al "oscuro rincón de la memoria» $\mathrm{y}$, además, concretiza y vivifica cicrta clase de malos recuerdos, "abcjas" que acosan su alma y la aguijonan:

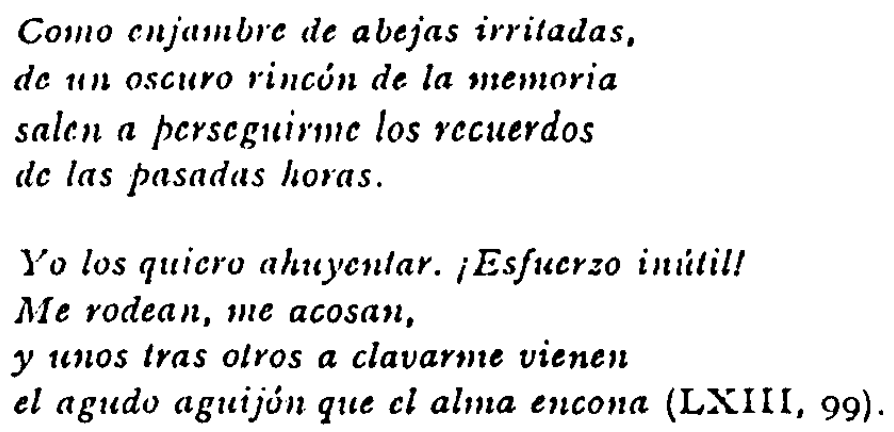

Sin embargo, con los recuerdos se fabrica la poesía y son uno de sus mejores materiales, según exclama Bécquer en la rima IV:

micultas hay'u esperanzas y recuerdos, ¡habri pocsla! (IV, I9).

Lin otros términos, según nuestro poeta, la poesía se hace con vivencias del pasado y con sueños del futuro. En clla se reconoce $y$ recrea lo vivido y se crea lo por vivir.

Ein rigor, todas las Rimas son la poetización de recuerdos vivenciales, psicológicos, y la ensoñación de visiones y ámbitos que están más allá de la existencia. Hay ell ellas una memoria hacia atrás y otra hacia adelante, por decirlo así: recuerdos de vivencias y recuerdos de sueños, de lo que, si no fue ni será, puede ser algún dia y en alguna parte.

Hay rimas que evocan con gran acuidad las imágenes - de la amada, principalmente - recogidas por la memoria que, alguna vez, salen de ella y son contempladas de nuevo por los ojos exteriores:

Te vi un punlo y flotando ante mis ojos

la inagen de tus ojos se quedó.

A donile quicra que la visla clavo

torno a ver sus pupilas llamear... (XIV, 36).

La memoria poética es una re-contemplación de lo real, sobre todo, cuando media el amor; y una re-ensoñación también de lo soñado.

Sin embargo, en la rima LVIII, Bécquer -desengañado del amor que soñara eterno- quiere conformarse con el anor de un día, porque no quiere sufrir nuevamente ni engañarse, como en la rima LII: 
¿Quieres que conservemos una dulce memoria de esle amor?

Pues amémonos hoy mucho y mañana digámonos jadiós! (LVIII, 192).

I a memoria es un espejo multiplicador e intensificador del dolor: de alıí que el pocta quiera librạrse de clla en un momento de desengaño anioroso:

\title{
Llevadme por piedad a donde el vérligo con la razón me arranque la menoria. ¡Por piedad! ;Tengo miedo de quedarme con mi dolor a solas! (LII, 84).
}

La memoria, por último, le trae el recuerdo real y constante de una muerte, contemplada $y$, por tanto, vivida, según vemos en la' rima LXXIII:

\author{
In las largas noches \\ del heludo invierno \\ (1................. \\ de la pobre niña \\ a veces me acuerdo... (IXXIII, II5).
}

Porque la memoria revive el dolor, el poeta anhela el olvido; la negación del espacio y del tiempo:

Callad: que por mi parle yo to he olvidado todo $(\mathrm{XI}, 72)$.

El olvido total es, naturalmente, el del sueño físico, el del dormir, al cual se acoge el poeta. Olvido que, en la rima LXXI, parece tener cuerpo - posee "brazos"- $y$, por tanto, ocupar un espacio, poéticamente hablando:

Entró la noche y del olvido en brazos cal cual piedra en su profundo seno (LXXI, 109).

9. La voluntad.-Según la Esscolástica, es una de las dos facultades racionales del alma humana, y nos mueve a hacer o no una cosa. Aunque la voluntad es libre, está restringida en el ejercicio de su libertad por la imaginación, la emoción y el hábito.

Aunque el voluntarismo becqueriano está presente en la estilística de las Rimas - abundancia verbal (sobre todo, de verbos de movi- 
miento) en la sintaxis-1, la voluntad como tal -es decir, como facultad racional del alma humana- estí presente en la rima XI.VIII, en dotide el poeta la usa casi heroicamente para expulsar de su alma la imagen de la anada:

\author{
Del allar que le alci en ol alma mia \\ la voluntad su imagen arrojó. \\ y' la luz de la fe que en clla ardia \\ anle el ara desierla se apagó. \\ Aun para combatir mi firme empeño \\ viene a mi mente sil visión tenaz... (XLVIII, 80).
}

10. La fanlasia (imaginación).-A diferencia de la memoria, es la facultad de unir libremente contenidos representativos. Extrae su material de los recuerdos, pero lo combina de manera libre para constituir nuevas formas. En el ejercicio de su actividad, está íntimamente ligada a las leyes de la asociación, asi como también a las esferas del sentimiento y de las tendencias del alma y de la personalidad del sujeto. lin cambio, por la dirección libre o pasiva de la atención queda puesta al servicio de la actividad creadora intelectual. Iis necesario recordar la inportancia de la fantasía en la conciencia onírica de los sucinos, en cl juego, en las fábulas y mitos y en todo pensar creador.

La fantasía desempeña su papel más importante como fantasi، creadora, al servicio de las "inspiraciones» de orden artístico principalmente. 'Todo pensar creador requicre en el hombre de manera natural el auxilio de la innaginación con sus representaciones y su libertad inventiva, con sus libres movimientos: de sus complejas complementaciones surge, a menudo, un contenido cognoscitivo insospechado y nuevo.

A pesar de que las Rimas "Son la historia verdadera de tha vida y de un alma" ${ }^{2}$, se convierten en poesía - no sólo por una sabia técnica-, por la intervención de la fantasía en su mundo interior y en las visiones oníricas que contienen.

Béccuer, al presentar en la rima III la polaridad 'inspiración-razón' -que solamente ha de resolver y unificar el genio-, muestra hasta qué punto la inspiración poética arranca de la fantasía, sabiendo crear inusuales asociaciones y comparaciones. I,o real y lo soñado se entretejen en el ámbito de la imaginación: ideas con huracanes y olas; el nur-

1 Cf. Concha '/akdoya, op. cil., pp. 58-69.

2 Jid. p. 80. 
mullo del alma con las señales del volcán, seres imaginarios e imposibles con paisajes vagorosos, ideas con cadencias, memorias con deseos ade cosas que no exislenn (15), etc. El trabajo de la razón opera sobre este magma de fantasías y de realidades.

Pero en las rimas que contienen o describen sueños o visiones es clonde comprobamos la fuerza creadora de la fantasía poética becqueriana. A causa de ésta, los sueños -en la vigilia del dormir-crean espacios poéticos por donde vagan las imágenes soñadas o entrevistas oníricamente:

No dormla: vagaba en ese limbo en que cambian de forma los objetos. misteriosos espacios que separan la vigilia del sueño (LXXI, 108).

isla de sueños donde reposa

el alma ansiosa... (I,XXII, I I0).

$Y^{\prime}$, soñando con los ojos de la amada, Bécquer nos dice en la rima XIV:

cuando duermo los siento que se ciernen de par en par abiertos sobre mi (XIV, 36).

Los sueños en que aparece la mujer amada se prodigan en las Rimas; algunas veces, el poeta mismo se introduce en ellos, soñándose:

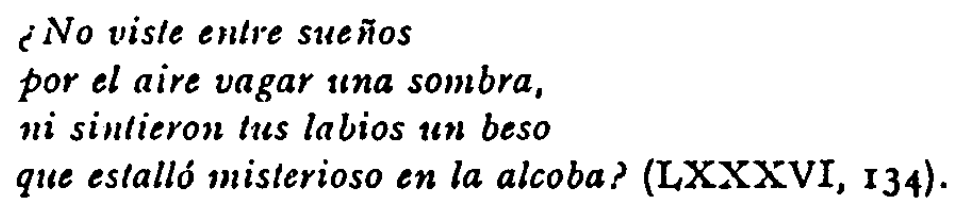

El espacio real se confunde con el onírico en el mundo de la fantasía:

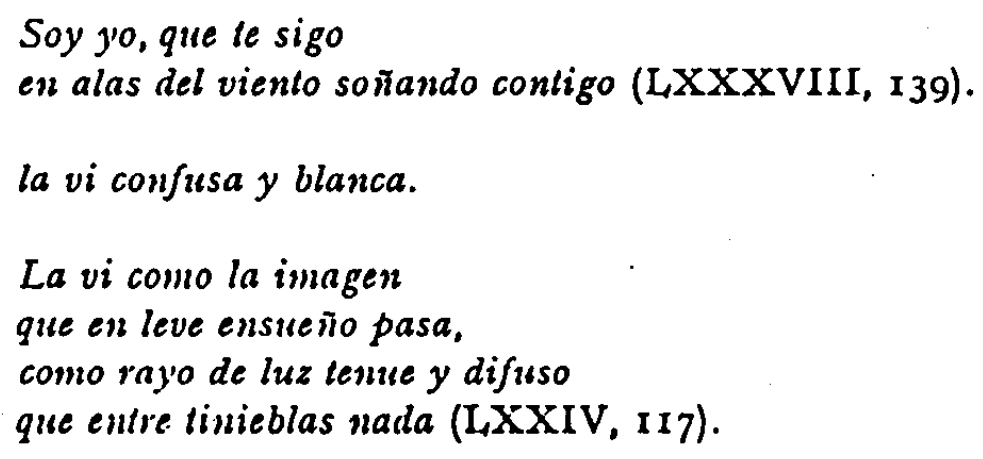


Lo real y lo irreal se atraen misteriosamente. Todo es sueño o, como en la rima LXXXIX, quizá sea el delirio de la fiebre:

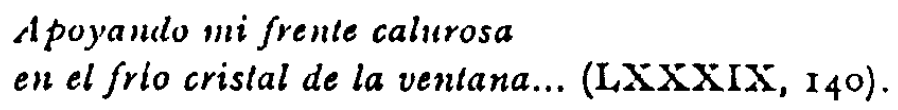

La estrofa final nos deja la impresión equívoca de lo que no sabemos real, porque fluctúa entre lo onírico y lo alucinatorio:

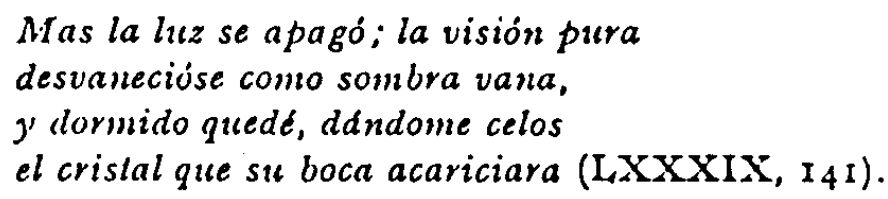

lin la tima LXVIII el poeta sufre hasta en sueños, aunque no sabe exactamente qué ha soñado:

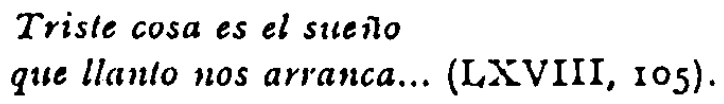

lil pocta, animado por el amor, posee la capacidad de leer los sueños de la que ama, lo mismo que sabe leer sus pensamientos:

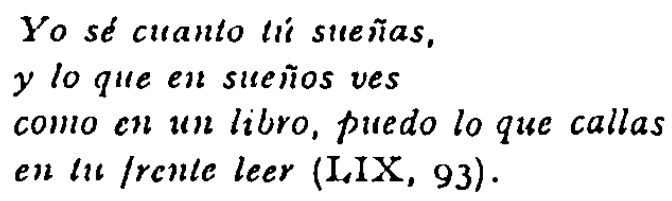

Iîn la rima $X V$, Bécquer parece entrever en su visión a la amada ideal, a la Belleza que ni muere ni acaba: es el sueño platónico:

$$
\begin{aligned}
& \text { iYo, que a lus ojos en mi agonia } \\
& \text { los ojos vuelvo de noche y dia; } \\
& \text { yo, que incansable corro y demente } \\
& \text { tras una sombra, tras la hija ardiente } \\
& \text { de una visión! }\left(\mathrm{XV}, 3^{8)}\right. \text {. }
\end{aligned}
$$

I a última validez del sueño es la de saberlo asociado a la vida y a la muerte. Las rimas en que aparece con esta comotación, acaso sean las más profundas, a pesar de que la idea central sobre la cual giran no sea demasiado nueva.

Iil tema de la vida como sueño lo encontramos en las rimas LXIX y IXXX. İn la primera, el poeta lirifica el breve existir del hombre usando la imagen del "relámpago" y convierte en sueños, adenás, el amor y la gloria: 
Al brillar de un reldmpago nacemos $y$ aun dura su fulgor cuando morimos: itan corto es el vivirl

La gloria y el amor tras que corremos sombras de un sueño son que perseguimos; idesperlar es morirl (LXIX, 105).

E1 sueño existencial reaparece en la rima LXXX, ligado al sueño del amor, y despierta resonancias del Barroco:

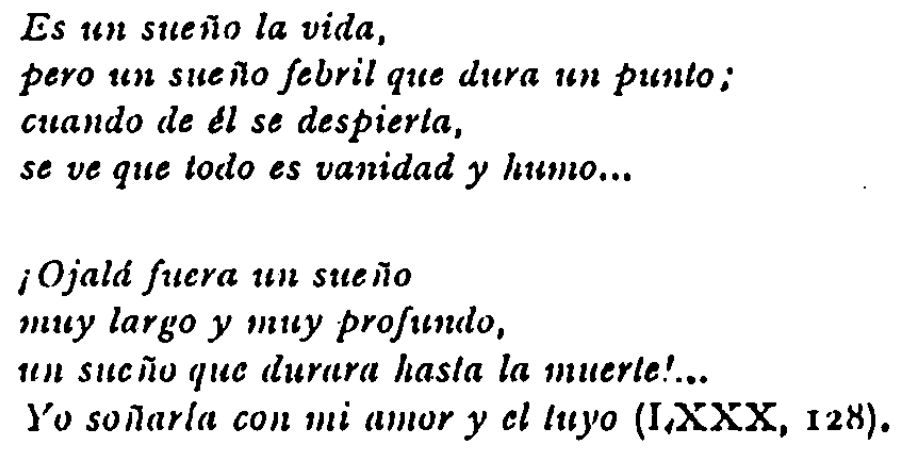

Al fin, el sueño se identifica con la muerte a la que aspira el poeta para, ell ella, dejar de soñar. Bécquer evoca, en la rima XLVIII, la muerte como un sueño sin sueños:

\section{Cuándo podré dormir con ese sueño en que acaba el soñar! (XI,VII, 80).}

Bécquer of rece, en sus visiones oníricas, juegos de inágenes aparentemente desordenados y carentes de sentido preciso, a los que faltan la guía del pensamiento lógico. Pero sus asociaciones demuestran la amplitud de su fantasía poética en el estado de la vigilia: el resultado es líricamente valioso, pues estas rimas muestran una honda psicología dentro del juego aparentemente absurdo de los sueños y ensueños. Sus fantasías, entonces, pueden casi considerarse como símbolos que permiten al intérprete hábil penetrar en el núcleo inconsciente de la personalidad poética becqueriana.

II. El espiritu y la conciencia.-El espiritu tiene varias significaciones y caracteristicas que conviene recordar aquí: $\mathrm{I}$ ) originalmente, fue el principio (pneıma) animador, energético, ígneo, del mundo; 2) un ser capaz de conciencia y. comúnmente considerado como poseclor de voluntad e inteligencia; 3) ser inmaterial; 4) ser consciente incorporal; 5) el orden supersensorial e ideal del ser o reino de la mente 
-intelectual, racional, noético, estético, moral, sagrado $y$ divino ${ }^{1}$. ¿Cómo se revela 'el espíritu' - como tal- en las Rimas becquerianas?

Lin la III, el espíritu -poseído por la locura de la inspiración poética que es también "cmbriagucz divina" (15) - se exalta y desfallece; es decir, es capaz de acrecentar su don sobrenatural, su gracia particular y tocar los bordes del éxtasis. Iis capaz de ascender y de aniquilarse, a pesar de su inmaterialidad.

Lin la primera estrofa de la rima $V$, el espíritu es la primera definición de la poesía, con la cual se identifica originariamente:

\section{Esplritu sin nombre, indefinible esencia... $(\mathrm{V}, 2 \mathrm{O})$.}

Ein otras palabras: está dotado de razón, es un alma racional. liste espiritu innominado, ignoto, es el pncuma, el principio animador y energético de la poesía, como en la antigüedad lo era del mundo.

Lin la estrofa final de la rima vuelve Bécequer a afirmar todo lo gue sabe de la l’oesía: que es sólo espíritu e ignota esencia:

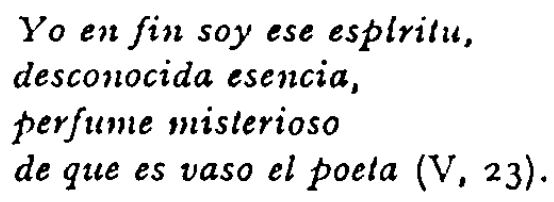

1 Iil 'espiritu' es el ser inmaterial, simple y sustancial, capaz de poseerse a sí mismo mediante la autoconciencia y la libre autodeterminación, asi como también de comprender y realizar valores suprasensibles (espirilı subjetivo). Su inmaterialidad no sólo excluye el ser-materia sino, además, aquella uintrinseca vinculación a la materian en virtud de la cual el alma de las plantas y de los animales no puede existir ni obrar sin estrechísima unión con lo corpóreo (Hilomorfismo). Su simplicidad implica una concentración tal de plenitud de ser y de fuerza que no permite la composición de partes esparcidas por el espacio ni esenciales. Lin la simplicidad y la inmaterialidad del espiritu se enraizan, de una parte, su capacidad para posecrse a sí mismo por la autoconciencia, y de otra, su aptitud para conocer todo ser en su verdad, bondad y unidad y para realizar valores suprasensibles. Iin su obrar, no restringido a un angosto dominio parcial de la realidad (como lo está el alma sensitiva, sintonizada sólo con los bienes de los sentidos), sino ordenado al ser sin más, el espiritu posee una abertura ilimitada de su facultad cognoscitiva, "afinada" para la verdad en cuanto tal $y$, como consecuencia, una expansión sin límites de su voluntad acordada" con el valor como tal. Iil espiritu posee gran amplitud de disposiciones y ejerce "soberania" sobre los valores parciales. l'osee aptitudes para la libre autodeterminación. A punta a la inmortalidad, pues exige una ilimitada permanencia del ser: no se llena por entero con bicnes caducos. Iil espiritu, como sujeto de esas perfecciones y posibilidades onto- 
Bécquer insiste en afirmar la condición indefinible de la Poesía, de la cual lo único predicable es que es 'espiritu', que su ser es inmaterial y que está dotada de razón: trasciende misterio.

In la rima XXV - ell que el poeta lo daría todo por la amada-, como ella es su alma, o se ha identificado totalmente con la suya, sólo puede entregarle - con el aire, la luz, el oro, la fama, el genio, etc.lo que es más íntimamente suyo: el espiritu, es decir, su alma racional, el aliento que fortifica su cuerpo:

$$
\begin{aligned}
& \text { diera, alma mia, } \\
& \text { por cuinlo espero, } \\
& \text { la fe, cl espiritu, } \\
& \text { la tierra, el cielo }(\mathrm{XXV}, 50) \text {. }
\end{aligned}
$$

En la rima XXXVII, ese mismo espíritu - vivificado, corporizado, ocupando un espacio- vivirá más allá del tiempo y de la muerte; está clotaclo de la voluntad de esperar y -metafóricamente, claro- de senlarse:

\author{
Anles que lii me morire: $y$ mi esplrills \\ en su cimpeño tenaz \\ se sentard a las puerlas de la muerte, \\ espercindole alld (XXXVII, 67).
}

lógicas es una esencia sustancial y su perfección funda de una manera natural el ser persona.

Iil 'espiritu' se relaciona con el alma espiritual, como forma sustancial del cuerpo. Como tal "forma constituye una unidad operativa en el conocimiento y tendencias sensoriales, estando también en el obrar espiritual unida, por lo menos indirectamente, a las condiciones previas de dicho obrar mientras dura la unión con el cuerpo. Por el querer y la vivencia del valor está ligado al alma entera sensitivo-espiritual. Desligada del cuerpo, el alma podrá manifestar más libremente su naturaleza espiritual con la visión intutiva de la propia esencia y del ser espiritual ajeno.

¿lis el espiritu enemigo de la vida? En realidad, el alma humana espiritual es el unismo principio de la vida. Con ello el espiritu lumano se exterioriza en to vital, pone frente a sí su antítesis no espiritual, pero no sólo como algo opuesto a lo espiritual, sino como campo de su actividad y de su expresión, unido por otra parte al ser total del hombre.

Cuando lo seusible-vital se sustrae a esta unidad del hombre entero para seguir únicamente su propia tendencia, actúa de un modo destructor.

Vil 'espiritu', finalnente, es lo más elevado que hay en el hombre y es el principio plasmador de todos los valores. Para los griegos, el 'espiritu' era aire incandescente.

(Cf. BRUGGik, op. (ill, pp. 182-184). 
Iinn esta visión postmortis, de trans-muerte, Bécquer afirma que el espiritu del amor es inmortal, aunque fallezca el cuerpo que lo conticne.

lin la rima XXV - poema visionario también-, el espiritu es libertado del cuerpo por el sueño:

\author{
¿Scrd verdad que cuando toca el sueño \\ con sus dedos de rosa nuestros ojos, \\ de la cdrcel que habita huye el esplritu \\ ell vuelo presuroso? \\ ¿Será verdad que huésped de las nieblas, \\ de la brisa nocturna al tenue soplo. \\ alado subc a la región vacla \\ a enconlrarse con otros? \\ ¿Y allt desindo de la humana forma, \\ alli los lazos terrenales rotos, \\ breves horas habila de la idca \\ al munlo silencioso? \\ ¿Y ric y llora y aborrece y ama \\ y guarda un rastro del dolor y el gozo, \\ semejante al que deja cuando cruza \\ el cielo un meteoro? \\ Jo no se si ese mundo de visiones \\ vive fucra o va dentro de nosotros: \\ l'ero sé que conozco a muchas genles \\ a quienes no conozco (XXV, I 19-120).
}

Aquí, Bécquer afirma la immaterialidad del espiritu y la vieja idea cristiana de que el cuerpo es cárcel del alma. Pero notemos que el poeta ha cambiado ésta por 'el espíritu', perfecta esencia sustancial y llena de perfección ontológica. Ese espíritu, naturalmente, también es ualma cspirilualn, como forma sustancial del cuerpo.

Iin la rima XI,II, 'el espíritu' se diferencia de 'alma' y se identifica con 'conciencia'. Lil alma sensible es capaz de pasiones - "iras", "piedad". l.a pérdida de la conciencia espacial -experimentada por Bécquer al saber el engaño de la amada - le lleva a una pérdida de la conciencia interior ${ }^{1}$, a la aniquilación - por decirlo así- de su espíritu al cual vivificaba el amor:

- Recordemos acui los éxtasis de los misticos y de los grandes poctas de la dlstica española y universal. 


\author{
Cilando me lo conlaron sentl el frio \\ de una hoja de acero en las entrainas, \\ ine apoyé contra el muro, y un instante \\ la conciencia perdi de donde estaba. \\ Cayd sobre mi esplrilu la noche, \\ en ira y en picalad se anegú el alma \\ iy enlonces comprendl por qué se llora \\ $y$ entonces comprendl por que se malal (XI,II, 74).
}

En otras palabras -ante la pérdida de la conciencia, ese sensus intimus-, el espiritu deja de sentirse, pues no puede existir sin estar vivificado por el amor.

\title{
Conclusión
}

A través de nuestro análisis, los 'espacios interiores' de Bécquer han ido desplegándose y precisándose poco a poco. Nos laan revelado no sólo su complejidad - dentro de su sencillez-, sino también su colierencia. $\Lambda 1$ evocarlos como 'espacios', hemos podiclo llegar a distinguir los matices que los diferencian entre si y que también los objetivizan ante nuestros ojos $y$ ante nuestra sensibilidad. El corazón, la meute, el pensar, las ideas, la razón, el alma -espacio central y totalizador-, la memoria, la voluntad, la fantasía, el espiritu y la conciencia se han dinamificado, vivificado, hasta actuar como espacios vivos, casi como personajes del mundo psíquico becqueriano y del drama poético que contienen las Rimas.

Cuando examinemos los 'espacios exteriores' comprobaremos que el poeta comulga en su soledad con el universo. Al profundizar en ella, Bécquer profundiza también en la gran soledad del hombre, y los dos espacios -el espacio de la intimidad y el espacio del mundo- se hacen consonantes: las dos inmensidades se tocan, se confunden. Dintorno y contorno coinciden. Las dos esferas coexisten hipostáticamente. Las variaciones se complementan y se enriquecen de manera mutua. Las limas - tan breves y poco numerosas- se amplifican hasta llenar el universo, pues lo contienen. Jil micro y el macrocosmos se integran en ellas y se corresponden poéticamente: Gustavo Adolfo Bécquer supo darles colnerencia poética dentro de una síntesis genial hecha con palabras sencillas $y$ versos leves, mas llenos de profundidad trascendente y emoción temblorosa.

Bécquer, sí, ha sido, es y será siempre un poeta vigente.

Concira Zardoya

University of Massachusetts at Boston. 